\title{
Relational Vulnerability: The Legal Status of Cohabiting Carers
}

\author{
Author \\ Ellen Gordon-Bouvier, Oxford Brookes University
}

\begin{abstract}
In this article, I examine the legal position of those who perform caregiving work within the context of a cohabiting relationship through a novel relational vulnerability lens. I argue that the state, through privatising and devaluing caregiving labour, situates carers within an unequal and imbalanced relational framework, exposing them economic, emotional, and spatial harms. Unlike universal vulnerability, which is inherent and unavoidable, relational vulnerability can be avoided and reduced if the state were to acknowledge that humans are embodied and relational rather than self-sufficient and rational. Law's treatment of cohabiting carers reflects the state's broader tendency to value economic self-sufficiency, while confining caregiving to the private family. I argue that the state has a duty to respond directly to relational vulnerability and should aim to make cohabiting carers resilient. Resilience must involve the provision of material resources but should also have a normative commitment to achieving autonomy and equality for those marginalised by law and state policies.
\end{abstract}

\section{Introduction}

Feminist legal scholars have criticised English law's lack of concern for those who compromise their earning capacity to raise a family or perform other caregiving or socially reproductive labour 1 in the context of an unmarried relationship (Barlow et al. 2008; Barlow 2007; Douglas et al. 2009; Bottomley and Wong 2006). I adopt a novel approach to the debate through the

\footnotetext{
1 The term 'social reproduction' is defined as "biological reproduction; unpaid production in the home (both goods and services); social provisioning ... the reproduction of culture and ideology; and the provision of sexual, emotional and affective services (such as are required to maintain family and intimate relationships)" (Hoskyns and Rai 2007, 300). Although the article predominantly focuses on caregiving, many of the cases also involve other unpaid work, such as looking after the home or working unpaid in the family business.
} 
development of a 'relational vulnerability' framework that I employ as a lens through which to analyse the modern-day legal position of cohabiting carers, acknowledging that society has moved on from the image of the caregiver as the traditional, financially inactive housewife, around which much feminist analysis in the 1980s and 1990s was based. However, as I argue, many of the issues that troubled feminists three decades ago remain today, albeit that they have been rendered more complex by an increasingly neoliberal political landscape.

I argue that cohabiting carers are relationally vulnerable, meaning that they are situated within an unequal network of relationships in which they are marginalised, and exposed to harm on an economic, emotional, and spatial level. I examine how ostensibly private interpersonal relationships are shaped by wider forces, including law (Nedelsky 2011). Relationships where one party undertakes all or most of the caregiving and socially reproductive labour are inherently unequal because the state does not adequately value or acknowledge this type of work. Here, I employ a broad definition of state, acknowledging that "the domain we call the state is not a thing, system, or subject but a significantly unbounded terrain of powers and techniques, an ensemble of discourses, rules, and practices" (Brown 1992, 12). This article is predominantly concerned with how law constructs care as a gendered, unproductive, and privatised endeavour. However, my analysis must be viewed in its wider context, whereby care is devalued through various means, including public discourses, social policies, employment practices, and the administration of the welfare benefits system.

I build upon and expand the boundaries of Martha Fineman's influential theory of universal vulnerability, which has shaped the scholarship in this area. Fineman's $(2008,2010,2017)$ core thesis is that vulnerability is a constant and unavoidable state, arising from the embodied and socially embedded nature of the human condition. To be human is to be susceptible to "the ever-present possibility of harm and injury from mildly unfortunate to catastrophically devastating events" (Fineman 2008, 9). For Fineman (2010), the problem is not vulnerability 
itself but, rather, that liberal and neoliberal state policies, laws, and institutions deny vulnerability, imagining instead that personhood is characterised by rationality, individualism, and self-sufficiency, thereby stigmatising those who cannot conform to the artificial ideal.

Fineman (2008) is critical of suggestions that some individuals can be viewed as more, or less, vulnerable than others, as this, in her view, undermines the claim that vulnerability is a universal and constant state. Yet, my relational vulnerability framework, by focusing on the specific vulnerability of cohabiting homemakers, does claim that some are more vulnerable than others. The difference, I argue, is that we are discussing different things. I do not see vulnerability as having only one cause. Everyone is vulnerable by virtue of being human, but some are affected by additional vulnerabilities. Humans are inherently relational but being relational is not the same as being relationally vulnerable, the latter of which relates to where one's relationships are unequal or unbalanced. Unlike universal vulnerability, relational vulnerability would be avoidable if the state, and law, were to foster positive and empowering relational networks.

Relational vulnerability does not deny the existence of universal vulnerability. Indeed, the cause of relational vulnerability is a state failure to acknowledge the embodied and embedded human condition; that we are all to varying extents dependent on the care of others for our existence (Nedelsky 2011; Fineman 2017). Yet, the state does not value those who perform caregiving labour. Instead, its institutions, including law, are structured to marginalise care, depicting it as a labour of love with little value outside the private family unit. This marginalisation is mirrored in the cohabitation case law, where caregiving is reconfigured to suit the dominant construction of care as either commercialised and transformed into a bargain, or sentimentalised and deemed incompatible with financial recompense. Law relies on an atavistic and heteronormative conception of care as a woman's relational role, which is evidenced in its greater tendency to commercialise domesticity where the claimant is male. 
The relational vulnerability lens allows transformation of the existing discourse around cohabitation and relationship-generated disadvantage. It reconceptualises the hardships experienced by cohabiting carers as state-created rather than the self-inflicted results of poor choices. Whereas relationship-generated disadvantage has traditionally been understood purely as an economic imbalance, the relational vulnerability lens promotes a broader understanding of the impacts of performing caregiving work within a cohabiting relationship. This holistic conception of relational vulnerability, together with exposing the state's vested interest in undervaluing care, prompts a change of approach, recognising the need for redressing the imbalances the state, through the legal framework, has helped to perpetuate.

I begin by outlining law's treatment of informal caregiving in the context of cohabitation, outlining the constructive trust and proprietary estoppel frameworks that govern rights in the family home. I then set out my theoretical framework, explaining that the way cohabitants are treated in law is based on an unrealistic image of a rational, autonomous legal subject. This contributes to the creation of relational vulnerability, which is a temporal condition arising during the relationship, but often with long-term impacts. Finally, I consider the question of resilience. Relational vulnerability is state-created and demands an urgent and active state response. Here, I consider the normative goals of caregiver resilience, mapping these against two hypothetical state responses to cohabiting carers.

\section{Cohabiting Carers and Relationship Generated Disadvantage: Legal Responses}

The imagined caregiver in this article is someone who, in the context of a cohabiting relationship, undertakes the majority of caring and socially reproductive labour, often giving up or compromising her earning capacity to do so. The most common scenario is undertaking childcare and assuming responsibility for the household, but some of the cases discussed also involve caring for an adult, such as elderly parents or parents-in-law. I should clarify here that my emphasis is on how cohabiting caregivers are treated in family and property law. I do not, 
for instance, deal with the provisions of the Care Act 2014, which, although a ground-breaking piece of legislation in terms of giving legal status to carers, focuses predominantly on caring for adults, and would not be applicable in most of the cases discussed in this article. Cohabitants who compromise their earning capacity through caregiving are particularly disadvantaged because English law does not have a specific statutory regime for property redistribution upon cohabitation breakdown. By contrast, where the couple is married, it is now recognised that the court can financially compensate one spouse for "relationship generated disadvantage",2 in recognition that "the marriage has deprived her of what otherwise she might have had".3

Disputes between unmarried couples over family property (usually the home) are dealt with by the ordinary law of property and trusts. A claimant seeking to assert a proprietary interest must establish a constructive trust based on the parties' common intention. This can arise in one of two circumstances. The first is where the claimant is not a legal owner, but nonetheless asserts that there was an intention that she 4 should have a beneficial share. If the parties expressly discussed ownership, the claimant can succeed if she shows that she relied on these discussions to her detriment by performing some act that she would not otherwise have done.5 Alternatively, the court can infer a shared intention from the parties' conduct.6 Where there have been express discussions, unpaid care could conceivably constitute detrimental reliance. However, the claimant must show that her contribution was motivated by the expectation of proprietary rights, which has been translated into a requirement that caring contributions be "out of the ordinary" 7 and not motivated by other factors, such as natural affection, or a desire to improve the parties' relationship. 8

\footnotetext{
2 Miller v Miller; McFarlane v McFarlane [2006] UKHL 24

3 SRJ v DWJ [1999] 3 FCR 153, 160 (Hale J, as she then was)

4 The feminine pronoun is used throughout to refer to either male or female persons

5 See Grant v Edwards [1986] Ch 638

6 Lloyds Bank v Rosset [1991] 1 AC 107

7 Thomson v Humphrey, [2009] EWHC (Ch) 3576, [44] (Warren J)

${ }_{8}$ See James $v$ Thomas [2007] EWCA Civ 1212
} 
Conduct from which intention can be inferred was traditionally interpreted narrowly, operating to the detriment of claimants relying on caregiving contributions. In his infamous speech in Lloyds Bank v Rosset, Lord Bridge declared that he was "extremely doubtful whether anything less than direct contributions to the purchase price by the partner who is not the legal owner"9 would suffice to infer that the parties intended to share beneficial ownership. Although Rosset remains the highest authority on sole ownership, subsequent obiter comments suggest that "[t]he law has...moved on" and that common intention should now be gauged from the parties' "whole course of conduct in relation to [the property]".10 However, more recent sole ownership cases have been interpreted inconsistently by the lower courts, with some continuing to rely on Rosset, and others taking a more holistic approach, and so it is unclear the extent to which the law has moved on (Sloan 2015).

In the second scenario, the parties are joint legal owners but are in dispute over the size of their respective beneficial shares. Following Stack v Dowden,11 where the parties are in a noncommercial relationship, there is now a strong presumption that they intended equal beneficial shares, irrespective of whether they made unequal financial contributions to the purchase price. Therefore, the joint-owner carer will be prima facie entitled to a half share of the home, unless it can be established that the parties in fact intended unequal shares. Stack and the subsequent Supreme Court case, Jones $v$ Kernott, 12 have been praised for demonstrating a more familycentred approach (Gardner and Davidson 2012; Hayward 2012). However, it would be an overstatement to claim that the presumption of an equal share has remedied the problem. As Baroness Hale recognised in Miller v Miller; McFarlane $v$ McFarlane, "[g]iving half the present assets to the breadwinner achieves a very different outcome from giving half the assets

\footnotetext{
9 Lloyds Bank v Rosset, n 6, p 133 (Lord Bridge)

10 Stack v Dowden [2007] UKHL 17, [60] (Baroness Hale, as she then was)

11 Ibid

12 Jones $v$ Kernott [2011] UKSC 53
} 
to the homemaker with children".13 In particular, a caregiver may find that a lump sum will affect her eligibility for benefit payments if she is unable to use it to purchase another property.

The doctrine of proprietary estoppel has significant overlaps with the constructive trust. Here, the claimant must show that she relied, to her detriment, on an assurance or promise by the owner that she was to have some interest in the home.14 It can be useful where the facts negate beneficial ownership, e.g. where a promise is made to make future provision by way of a will. Proprietary estoppel has been successfully pleaded in a number of cases where a claimant has undertaken unpaid care in return for a promise of future financial provision. 15 However, it is remedially uncertain in that it does not guarantee the claimant a beneficial interest in property. Instead, the court must simply do the minimum necessary to satisfy the equity, which could mean an order for occupation or a monetary payment. Like the constructive trust, it requires evidence of an assurance or bargain of some sort; something that may be unrealistic in the context of an intimate relationship (Gardner 1993).

\section{The Changing Face of the Caregiver}

Any analysis of this area must take account of recent social and demographic changes to avoid reinforcing outdated stereotypes. As I argue in this section, the image of the cohabiting carer has undergone transformation over the past 40 years. Nonetheless, many of the old problems persist, albeit in a new and more complex form.

In Burns v Burns 16, Valerie Burns left her 20-year relationship in the mid-80s with no assets after the Court of Appeal rejected her claim for a constructive trust. The family home in which she had raised her children was owned by her partner. She could not point to evidence of an

\footnotetext{
13 Miller v Miller; McFarlane v McFarlane, n 2, [136] (Baroness Hale)

14 See Thorner v Major [2009] UKHL 18

15 E.g. Jennings $v$ Rice [2002] EWCA Civ 159; Re Basham [1986] 1 WLR 1498; Wayling v Jones [1995] 69 P\&CR 170

16 Burns v Burns [1984] Ch 317
} 
express agreement that she was to have a share in it, and her caregiving and homemaking contributions were insufficient for the court to be able to infer a common intention of beneficial ownership. She was left destitute. The full extent of her fate is not revealed in the Court of Appeal judgment, but a subsequent television documentary revealed that she was forced to live in her car in a roadside layby following the separation.

Valerie Burns has become symbolic of the law's unfairness and harshness towards (predominantly female) homemakers (Bottomley 1998). However, more recent commentators have questioned the extent to which we can assume that women in unmarried heterosexual relationships continue to bear a resemblance to the traditional housewife that concerned feminist legal scholars in the 1980s and 1990s (Probert 2001; Auchmuty 2016). Widespread societal and political change has taken place since Burns was decided. Women's participation in the workplace has continued to increase and, unless couples can afford to live on one wage, it is fairly unusual for one partner to have made no financial contributions at all towards the home. Furthermore, the state's expectations of its citizens have shifted significantly. The male breadwinner/female homemaker model prevalent until the latter part of the twentieth century, has given way to an "adult worker model" (Smith 2014), whereby all citizens are expected to be economically active, regardless of caregiving obligations.

However, while today's caregiver often has greater financial autonomy than her 1980s counterpart, the questions of financial dependency, enforced domesticity, and feminisation of reproductive labour that feminists discussed three decades ago (and indeed far before this) have not been satisfactorily resolved. Instead, the situation of carers and the care debate has been complicated in ways that must be confronted by legal researchers. For example, the carer's participation in the workplace brings additional challenges in terms of juggling the demands of work with those of the home. She may find her leisure time depleted, impacting on her physical and mental wellbeing. Furthermore, female members of the middle classes can purchase 
financial autonomy by delegating their caregiving labour to more marginalised members of society, often migrants and women of colour (Meagher 2002).

One problem remains relatively constant. While law and policy rely on increasingly genderneutral language to describe caregiving, such as recategorising maternity leave as shared parental leave, women continue to perform the majority of unpaid informal care and domestic work in the home (Crompton and Lyonette 2008, 2015). Even where men perform caregiving work, their experiences are different to women's, with women spending a greater number of hours providing care, receiving less support, and experiencing greater adverse physical and psychological effects (Pinquart and Sörensen 2006; Penning and $\mathrm{Wu} 2015$ ). Women also tend to bear a greater 'mental load' in terms of having overall responsibility for coordinating the household, even if tasks are shared between partners (Everingham 2002; Hochschild 1983).

Thus, while image of the caregiver has changed from a traditional housewife to an increasingly economically active (but overburdened) worker (Lewis 2001), care remains imagined as a female endeavour. Relief is available to those who can afford to purchase commodified caring services, but this entrenches class and racial divides and further marginalises those who are already oppressed (Roberts 1997; Luxton 2002).

\section{The Vulnerability Lens: Universal Vulnerability}

As outlined in the introduction, Fineman's theory of vulnerability argues that all humans are inherently vulnerability by virtue of their embodied and socially embedded nature. Universal vulnerability is the starting point for Fineman, but her theory is ultimately a critique of the liberal state's failure to respond to the vulnerable reality of humanity, preferring instead to promote an image of personhood as rational, self-sufficient, and able-bodied. This hypothetical liberal subject is fixed in time; its powers and capacities never deteriorating, its body never 
ageing. This view of human nature is not only unrealistic, but actively harmful, as it stigmatises those who cannot conform to the invulnerable norm (Fineman 2008).

While proponents of the universal thesis have argued that it is unhelpful to use the language of 'vulnerable populations' (Fineman 2008, 2015; Travis and Garland 2018), they do acknowledge that universal vulnerability is not experienced uniformly. For instance, some people are incredibly wealthy, while others live in desperate poverty. Yet, this contrast does not mean that the rich are not vulnerable. Rather, it reflects that individuals possess varying levels of resilience, meaning material resources, capital wealth, and access to certain social networks and institutions (Fineman 2008; Travis 2018). Thus, a resilient individual is still inherently vulnerable, but she has the means to minimise the extent to which she is disadvantaged or restricted by it. The state distributes resilience unequally, but this is concealed by a dominant political rhetoric of personal responsibility, whereby the individual is blamed for failing to become resilient (Fineman 2010).

\section{Relational Vulnerability: A 'More than Ordinary' Vulnerability}

I theorise the relational vulnerability to which cohabiting carers are subject as an additional, or "more-than-ordinary" (Sellman 2005) vulnerability that exists in addition to the embodied vulnerability which affects all humans. While this approach may draw criticism of labelling cohabiting homemakers as a 'vulnerable group', I view it as an extension rather than a contradiction to the universal thesis. I do not deny the inherent vulnerability of the human condition, but I argue that this is not the only form of vulnerability. Instead, I view vulnerability as having a variety of sources, including social, environmental, and relational ones (Mackenzie et al. 2014; Lotz 2016). Being specific rather than general when discussing vulnerability, I argue, enhances understanding both how vulnerability is experienced and how it can be responded to. 
While relational vulnerability is additional to universal vulnerability, the two concepts are inextricably linked. Relational vulnerability arises because, as Fineman (2017) argues, humans are both embodied and in need of care, and relationally embedded. In conceptualising relationality, I draw on Nedelsky's (2011) concept of "nested relations", which views the individual as situated within an extensive web of interactions, both with other individuals and with the state and its institutions, including law. Interpersonal relationships do not arise in a vacuum; they are shaped and governed by wider influences. Cohabiting carers are relationally vulnerable because they are situated within an unequal or unbalanced relational network. Their disadvantages cannot be attributed to poor personal choices (such as the decision to make career sacrifices or the decision to not get married). They arise because the state marginalises and devalues care, giving caregivers a low status within their relational networks. As a result, I argue, caregivers are exposed to economic, emotional, and spatial harms. Some people can emulate the unrealistic ideal of the liberal autonomous subject, but only because others are performing caregiving labour. However, because the state largely ignores or privatises care and dependency, it points to these unburdened individuals as representative of ideal citizenship, while stigmatising carers for failing to attain economic self-sufficiency.

I do not view it as problematic to identify certain groups who experience additional vulnerabilities over and above the inherent biological vulnerability that affects us all. Fineman herself accepts that there are variations in levels of resilience between groups. To an extent, the conflict between our approaches is one of nomenclature. I could describe cohabiting carers as 'less resilient' rather than 'vulnerable', due to their reduced access to the resources that would help them withstand the impact of the inevitable vulnerability that affects us all. However, I argue that this would be an inadequate theorisation of their position. There is, in my view, importance in emphasising the conceptual distinction between vulnerability as the source of harm and resilience as the response to it. Cohabiting caregivers do not merely suffer 
from an absence of resources. Rather, they are actively exploited by a state that draws significant benefits from their unpaid work without rewarding them, while simultaneously stigmatising them for failing to live up to an impossible self-sufficient ideal. The legal framework helps to perpetuate this exploitation. Thus, the label of more-than-ordinary vulnerability, instead of lack of resilience, helps to emphasise the state's, and the law's, role in creating harmful relational networks that disadvantage caregivers.

\section{Law's Creation of Relational Vulnerability: The 'Rational Subject' and the 'Altruistic}

\section{Carer'}

I now turn to the process by which the legal framework helps to situate cohabiting caregivers within an unequal relational network. The state's devaluation of care is constant, pervasive, and entrenched. Its institutions, particularly the private family, are structured to privatise responsibility for caregiving and remove it from public concern (Fineman 2008). Care is decoupled from economic value, creating an illusion that 'love is all you need' to be a carer, ignoring that effective caregiving is dependent on access to adequate economic and social resources (Fineman 2004). Simultaneously, the neoliberal state's veneration of financial independence reinforces carers' low status because their unpaid caring responsibilities prevent them from complying with the economic ideal. Carers become trapped in an unbalanced relational framework: one that restricts choices and encourages unhealthy dependencies.

The legal framework applicable to cohabitants directly contributes to the privatisation, gendering, and devaluation of care, and to the marginalisation of cohabiting carers. Law, as a state institution, has considerable discursive and coercive power to shape relationships between citizens, and between citizens and the state (Berkovitch 1997). Yet, law explicitly denies its social and political force, claiming instead to be neutral, rational, and apolitical (FoxO’Mahony 2014; Davies 2011). In the cases concerning cohabitants, judges frequently reiterate that they are limited to impartially determining the parties' proprietary interests rather than 
ensuring substantive fairness. 17 Yet, even pronouncements such as this are politically loaded. Behind the façade of neutrality, the legal framework reinforces care as a gendered and sentimental endeavour. By positioning caregiving and relationality as inherently incompatible with the dispassionate logic of acquiring proprietary rights, law continually reiterates care's low status. Property law's dominant narratives construct caregivers as "outsiders" (FoxO’Mahoney 2014, 409), who do not belong within the legal framework.

I argue that the case law relies on two distinct fictional images, against whom legal actors are assessed. The first is the rational subject; a person embodying the neoliberal, typically masculine, ideals of self-interest and economic self-sufficiency. The foil to this character is the altruistic carer, an inevitably feminine role that represents the extra-legal emotional realm. The altruistic carer character reinforces the notion that care is "the moral duty of the good wife, mother or daughter, with no economic value as such but which is performed in exchange for the male breadwinner's legal and/or moral duty to provide financial support" (Barlow 2007, 251). Neither character is a realistic representation of personhood. Instead, they operate in tandem to privatise, sentimentalise, and feminise care, enforcing its lack of belonging within the public sphere of property rights.

Within the case law, the rational, self-interested legal subject and the feminine, self-sacrificing, altruistic carer are viewed as fundamentally incompatible. This has prompted judges to frame their narrative in such a way as to imbue legal actors with the characteristics necessary to emulate either of the two characters. In turn, this operates to either allow or deny compensation for caregiving. For instance, Flynn and Lawson's $(1995,119)$ discussion of Wayling $v$ Jones, 18 which involved caregiving and domestic work in the context of a male same-sex couple, noted the manner in which the court felt it necessary to "explain (and to elevate) [the claimant's]

${ }_{17}$ See e.g. Curran v Collins [2013] EWCA Civ 382, [19], (Toulson LJ) 18 Wayling $v$ Jones, n 15 
domestic behaviour in the description of him acting as companion or chauffeur in exchange for monetary support". More recently, in Culliford $v$ Thorpe, 19 which also involved a male samesex couple and the performance of unpaid domestic work, HHJ Matthews used notably contractual language, explaining that the court's task was limited to "implementing the agreement- the informal bargain- between [the couple]"20. As in Wayling, what was a personal and intimate relation had to be moulded into a market-based transaction where the parties negotiated for their rights.

The judicial commercialisation of personal relationships often glosses over evidence of affection and relationality, sometimes producing inconsistencies in reasoning. Thorner $v$ Major,21 although it does not involve cohabitants, illustrates these contradictions. Here, the claimant (David) had worked unpaid on his father's cousin's (Peter) farm for 30 years, until the latter's death. As Peter grew increasingly elderly, David had also assisted him with day-today tasks. The House of Lords focused on David's lost commercial opportunities in justifying an award. Other features of the case suggested that David would have helped Peter even if there was no suggestion of financial reward. David had provided substantial assistance to his parents for nominal pay for many years, suggesting a strong sense of family loyalty within him that outweighed any commercial motivations. Lord Scott also doubted whether David would have objected to the farm being sold to pay for Peter's nursing care. 22 In addition, owing to Peter being "a man of few words" 23 , much of the 'bargaining' took place through assumptions, gestures, and even silences, leaving judges to fill the gaps. While the House of Lords attempted to expand the limits of bargaining, emphasising that "the meaning to be ascribed to words

\footnotetext{
19 Culliford v Thorpe [2018] EWHC (Ch) 426

20 Ibid, [78] (HHJ Paul Matthews)

21 Thorner v Major, n 14

22 Ibid, [19] (Lord Scott)

23 Ibid, [70] (Lord Neuberger)
} 
passing between parties will depend, often very much, on their factual context",24 the lack of fit between complex relational contexts and the commercial demands of proprietary estoppel was evident.

Where the claimant is female, courts are more likely to sentimentalise, rather than commercialise, her unpaid work, thereby denying her an interest in the home. The female claimant is cast in the role of altruistic carer, a character that is inherently incompatible with the notion of economic reward. This reflects the consistent feminisation of care within social and political discourse. In contrast to men, women are imagined as natural nurturers, fulfilling biological and social roles as mothers, wives, and daughters (Tronto 1994). Lord Bridge's by now infamous speech on unpaid domestic work in Lloyds Bank $v$ Rosset demonstrates the judicial tendency to see female domesticity and financial reward as inherently incompatible. As he reasoned:

it would seem the most natural thing in the world for any wife, in the absence of her husband abroad, to spend all the time she could spare and to employ any skills she might have, such as the ability to decorate a room, in doing all she could to accelerate progress of the work quite irrespective of any expectation she might have of enjoying a beneficial interest in the property 25

As Lord Bridge's words demonstrate, the feminine altruistic carer character is closely tied to perceived female heteronormative relational roles. As a wife, there were certain behavioural expectations on Mrs Rosset, echoing that, within heterosexual relationships, women are required to perform unpaid work in return for financial support from a male partner (Fudge 2005; Pateman 1988).

While modern-day judges would no doubt be hesitant to express their views quite as explicitly as Lord Bridge did, more recent cases show a continuing tendency to associate women's work

24 Ibid, [80] (Lord Neuberger)

25 Lloyds Bank v Rosset, n 6, p 131 (Lord Bridge) 
with altruism. For instance, in James $v$ Thomas, Sir John Chadwick dismissed the claimant's claim for a constructive trust on the basis of unpaid work, explaining that:

The true position, as it seems to me, is that [the claimant] worked in the business, and contributed her labour to the improvements to the property, because she and Mr Thomas making their life together as man and wife ... It is a mistake to think that the motives which lead parties in such a relationship to act as they do are necessarily attributable to pecuniary self-interest.26

As in Rosset, the claimant was cast in the wife-role, with its expectations of altruism and unpaid work. Sir John Chadwick emphasises that he sees a clear distinction between relational motivations and what he calls "pecuniary self-interest". Similarly, in Thomson v Humphrey, where the claimant cared for the defendant's elderly mother, Warren J reasoned that:

There is absolutely nothing to link this conduct with the fact ... that she had an interest in [the property]. The reason she looked after the defendant's mother was surely because she lived with the defendant and did this because of her relationship with him and perhaps, for all I know, and this is pure speculation, because she got on with and liked the defendant's mother and did it for her. 27

Both James and Thomson demonstrate that the existence of intimacy is thought to negate any question of financial reward. Where the claimant is male, there appears a greater tendency to downplay the intimacy in favour of bargaining behaviour. Conversely, domesticity is emphasised in cases involving female homemakers, fitting the claimant into the altruistic carer role. HHJ Paul Matthews, the judge in Culliford, also heard the case of Dobson $v$ Griffey 28 a few months later. Like Culliford, Dobson concerned an alleged assurance to share the home, coupled with unpaid domestic work. However, while the judge was able to find a bargain in Culliford, in Dobson, he resorted to drawing inferences regarding intention from the female claimant's relational role, explaining that:

Her labour and commitment were understandable in the context of their relationship and their intended long-term future together with children. This was

\footnotetext{
26 James $v$ Thomas, n 8, [36] (Sir John Chadwick)

27 Thomson v Humphrey, n 7, [43] (Warren J)

28 Dobson v Griffey [2018] EWHC (Ch) 1117
} 
to be her home, and that of her children. It is unnecessary to suppose some quasicommercial bargain between them to explain it.29

The parties never did have children together, but the idea that this may have been a possibility was used to deny the claimant a remedy. It was "unnecessary" to go further than the fact that the claimant was simply doing what was expected of her in the context of a quasi-marital relationship.

\section{Elements and Temporality of Relational Vulnerability}

In this section, I consider how legal and social marginalisation comes to impact on cohabiting carers in various ways. In the literature and judicial discourse, relationship-generated disadvantage is discussed predominantly as a financial imbalance between the parties, and one that does not occur until the relationship breaks down. This, in my view, downplays the full extent of the impact on cohabiting carers of being situated within an unequal relational network. Instead, I argue, that the devaluation of caregiving labour exposes carers to a combination of economic, emotional, and spatial vulnerability. Furthermore, this vulnerability is potentially lifelong and cannot simply be temporally confined to the point of relationship breakdown.

The Temporality of Relational Vulnerability

The caregiver's relational vulnerability is a fluctuating condition arising during the course of an intimate relationship, albeit that it usually concealed behind the structure of the private family at this time. It intensifies and gains visibility upon relationship breakdown, particularly if the caregiver seeks to replace her dependency on her partner with dependency on the state. However, much of it consists of the future uncertainties that are engendered by being a carer in the present-day.

29 Ibid, [84] (HHJ Paul Matthews) 
Rendering temporalities visible can enrich critical legal scholarship (Kotiswaran 2015), particularly when considering how these temporalities interact with, and are shaped by, law (Grabham 2016). Time forms a significant, but often underexplored, component of vulnerability (whether inherent or more-than-ordinary). Universal vulnerability itself is tied to the temporal measure of the human lifespan, which moves through various stages, including infancy, childhood, adulthood, old age, and death. Some of these stages, notably infancy, render us completely dependent on receiving care from others, whereas at other points, our physical strength imbues us with "temporal powers" (Thompson 2014), bringing greater independence. However, time is unpredictable and to be human is to be vulnerable to the everpresent risk of one's life being disrupted by unforeseen events like accidents and illnesses (or these happening to those close to us), which, once again, bring about helplessness.

While humans seek to exercise control over time, artificially categorising it and often using it as an instrument of exclusion (Grabham 2016; Adam 1995), true dominion over time's passage is an impossibility. However, access to certain resources in the present day, such as pensions, health insurance, or real property, can help to provide a form of anchor to an otherwise uncertain future. A key component of the cohabiting carer's relational vulnerability is an absence of such anchoring. Becoming a caregiver can set in motion a future trajectory of hardship; one that is difficult, or even impossible, to change once begun. Upon relationship breakdown, cohabiting carers may experience a sense of 'lost' or wasted time, with certain opportunities having disappeared forever, including promotions, acquiring a home of one's own, accumulating savings, or even the chance of pursuing a more successful and stable intimate relationship with another person. A legal framework such as the existing one, that is unconcerned with future hardships, and instead conducts a retrospective relational survey to ascertain property rights, is inadequate for addressing this temporal aspect of relational vulnerability. 
Economic Vulnerability

Economic vulnerability refers to caregivers' potentially harmful economic dependency, both on intimate partners and the state. While family law recognises that taking on caring responsibilities can have significant economic repercussions, it views these as arising when the relationship comes to an end, and relatively little attention is given to financial inequalities that arise during the relationship. However, empirical research suggests that, on the whole, women in heterosexual relationships have less access to spending money than men and may even spend less on food for themselves than other members of the household (Cantillon 2013). This reflects the gendered distribution of care and household work, and the fact that women are less likely to be the family breadwinner (Pahl 1983).

The neoliberal state is largely unconcerned with unequal distribution of resources within the private family. As O’Donovan $(1985,12)$ has remarked, “[ $\mathrm{t}]$ he couple is a unit, a black box, into which the law does not purport to peer. What goes on inside the box is not perceived to be the law's concern". This allows the state to remain restrained, delegating responsibility for dependency to the family. Policies presume that money is shared equally, but there is no remedy when it is not. Under the current Conservative government, this restraint is becoming ever-more explicit, evidenced for instance by the introduction of Universal Credit, which is paid only to the 'household head', leaving women (particularly black and BME women) at serious risk of financial hardship if their partner refuses to share the money (Sandhu 2016).

Assumptions of equal sharing romanticise the private family, glossing over inequalities and harms that occur beneath its idealised surface. Often, arguments in favour of law reform for cohabitants is structured around notions of sharing and interdependency. For instance, Gardner (1993) argues that the law should acknowledge cohabiting relationships that are "materially communal", meaning that "[the parties] pool their material resources (including money, other assets, and labour" (Gardner and MacKenzie 2015, 3.7). This view is echoed in both Stack v 
Dowden and Jones $v$ Kernott. In Jones, the "emotional and economic commitment to a joint enterprise" 30 was used as justification for the presumption of equal shares in joint ownership cases. In Stack, the issue of intermingling of finances was seen as being of particular importance in demonstrating the parties' intentions. The fact that the couple had kept their finances "rigidly separate" 31 meant that the presumption of equal sharing could be rebutted.

Although the tendency towards communitarianism in joint ownership cases may appear a welcome departure from property law's traditional individualism, there is a danger of giving too much weight to the presence or absence of shared access to finances in cohabiting couples. Research has suggested that cohabitants are less likely than married couples to merge their finances and operate a joint account (Elizabeth 2001; Burgoyne et al. 2011). However, this fact does not by itself indicate greater financial equality between the partners. While separate finances may be a sign of autonomy and independence where the parties have equal access to financial resources, it can also signal the opposite where there is disparity in income positions. Geary $v$ Rankine 32 illustrates the dangers of law giving too much weight to the absence of sharing. Here, the parties had been together for 19 years and had a child. Throughout the relationship, Mr Rankine had refused to put his guesthouse business and an investment property into joint names despite Ms Geary having provided significant assistance with the business, giving up her job to do so. There were also hints at financial abuse, with Ms Geary asserting that "throughout our relationship the Respondent was mean with money [...] If I asked the Respondent for money to spend on myself other than small amounts, there would always be an argument and he would become angry so I eventually did not ask." 33 Responding directly to the allegations regarding Mr Rankine's refusal to share assets with Ms Geary, Lewison LJ

\footnotetext{
30 Jones $v$ Kernott, n 12, [19] (Lord Walker and Lady Hale)

31 Stack v Dowden, n 10, [92] (Baroness Hale)

32 Geary v Rankine [2012] EWCA Civ 555

33 Ibid, [7]
} 
thought that "[t]hose points to my mind contradict any conclusion that she had an entitlement to a share in profits of the business." 34 Thus, Ms Geary's failure to place her relationship within the idealistic dominant paradigm worked to her detriment, and the court was unconcerned with the inherently unbalanced financial dynamic between the parties.

Highlighting its temporally fluctuating nature, the true extent of economic vulnerability is often delayed until later in life. Being a carer substantially affects one's ability to make financial provision for retirement and old age. Women are more likely than men to experience older-age poverty, which has been attributed to their greater likelihood to have engaged in homemaker roles, including childcare and elder care (Orel et al. 2007; Ekerdt and Hackney 2002). While women today are more likely to be engaged in paid employment than in the past, they are less likely than men to have access to adequate employer pension schemes that will alleviate financial hardship in old age (Gough 2001). Even if their current caring obligations are timelimited (e.g. raising children), women have far a greater likelihood than men of their futures becoming punctuated by "disruptive life events" (Orel et al. 2004), including obligations of care for elderly parents or other relatives, often in conjunction with still caring for dependent children (Hooyman et al. 2002). In today's neoliberal era, where the welfare state is in retreat and caring services are becoming increasingly privatised, it is likely that expectations on women to perform elderly-care will intensify.

\section{Emotional Vulnerability}

I use the term emotional vulnerability to refer to the feelings of powerlessness, stress, and worry that accompany economic and spatial vulnerability. It results from unbalanced relational frameworks, where the carer's autonomy is subverted, and she comes to lack control over her decisions. Since money, and control of money, carries substantial social power (Zelizer 1997),

34 Ibid, [13] (Lewison LJ) 
the state's failure to provide resources directly to carers, forcing them to become dependent on partners, amounts to disempowerment. As Burgoyne $(2004,165)$ has argued, "the power that comes with being the breadwinner can be much more subtle and that even a joint account does not guarantee an equal say". This is also borne out in Pahl's $(1989,174)$ early research on married couples, which found that "husbands were more likely to dominate in decision-making where the wife did not have a job... conversely wives who were dominant in decision-making were usually in paid employment". More recently, a study of cohabitants identified so-called "uneven couples" characterised by power imbalances within the relationship, often also linked to financial inequality (Barlow and Smithson 2010). By delegating responsibility for caregiving to the private family, thus encouraging economic dependency, the state is placing carers at increased risk of exploitation by partners. Although economic dependency does not in itself cause exploitation, it produces conditions in manipulative or abusive behaviour to take root, as seen in Geary v Rankine.

Emotional harm does not merely result from the intimate relationship dynamic, but also from the carer's interaction with the state and its institutions. Caregivers' low social status can lead them to suffer so-called "harm to citizenship entitlements" from being treated as unproductive members of society (Rai et al. 2014, 92). Care is made incompatible with the autonomous ideals of citizenship because financial dependency (which is almost an inevitability for carers) under the liberal model is seen as "evidence of a failing to attain or retain autonomous agency" (Dodds 2007, 501). As Young $(1995,547)$ argues, “normatively privileging independence ... and making it a primary virtue of citizenship implies judging a huge number of people in liberal societies as less than full citizens".

While the move from the female caregiver ideal to the adult worker model has improved women's financial autonomy, it has also added potential additional psychological burdens on carers. The "second-shift" phenomenon refers to having to perform double duties in the home 
and the workplace, and the negative physical and emotional consequences that ensue (Hochschild and Machung 2012). As I discussed above, combining employment and caregiving is often dependent on being able to delegate care to others. However, this ability is not equally available to all, and requires access to financial resources. Whereas many middleclass, high-earning women can purchase help with childcare, lower-income immigrant women are more likely to be the ones to whom this care work is delegated. In turn, these women's second shifts can become even more pressured, having to combine professional caregiving with meeting the needs of their own families (Williams 2010). Yet this strain on more marginalised groups of women is often masked by (predominantly) white affluent women's increased presence in the workplace.

Because emotional vulnerability extends beyond the interactions between intimate partners, it can also continue after relationship breakdown. With the loss of the relationship's masking effect, the carer's economic dependency becomes publicly visible and she may need to support herself through the state welfare system. This process can take a significant emotional toll. Loxton's (2005) research on single mothers in Australia found that worries about an uncertain financial future were a common theme, caused partly by an inability to make long-term financial provision by way of savings or home ownership. As she explains, "sole mothers described their futures as 'bleak', 'scary', 'daunting' and 'not good'” (Loxton 2005, 42). Carers who are reliant on state benefits are also at constant risk that a change in political climate will lead to existing support being withdrawn. For the past 40 years, the state has tended towards increasingly neoliberal policies (Barlow et al. 2017). Welfare provisions have been gradually eroded, with an enhanced emphasis on self-sufficiency and personal responsibility. This can be a significant source of concern and stress for carers, with uncertainty over whether current schemes for assistance, such as the state pension, will even exist in the future. 
Spatial Vulnerability

Spatial vulnerability refers to the harm that results from having an insecure relationship to one's home, both during the relationships and in the future. The embodied nature of humanity means that, as well as existing in a web of interpersonal and citizen-state relations, we also have connections to the spaces that we inhabit. Human wellbeing is dependent on being able to live somewhere that is secure, both in a physical and a temporal sense, and for the relationship between individual and space to be protected and respected by the state. Strong spatial relationships are of particular importance for caregivers because care is directly dependent on a suitable space in which it can be performed (Williams 2002).

The home is a powerful combination of physical space, discourse, and ideology, and has been recognised as a source of individual identity, autonomy and security (Saunders 1989; Radin 1982). The idealised home has also become symbolic of a private sphere, offering a sanctuary and respite from the harshness of the outside world (Chapman and Hockey 1999). While individuals develop psychological connections to their homes over time through living in them and experiencing various life events (Gurney 1997), law also plays an influential role in terms of home as a source of identity and security. For example, Saunders (1989) has suggested that legal ownership engenders a stronger sense of security compared to rental accommodation. This perceived difference between the owned and the rented home has partly been explained on the level of control that the individual is able to exercise in relation to her spatial surroundings (Easthope et al. 2015). Ridgway et al. $(1994,413)$ have furthermore argued that “empowerment ... comes from controlling access to personal space, from being able to alter one's environment and select one's daily routine, and from having personal space that reflects and upholds one's identity and interests".

Rather than existing in a state of nature, legal property regimes are socially constructed and reflect societal norms and goals (Davies 2007). Laws of ownership involve the state making 
decisions as to who belongs where, often reflecting gendered and racialised patterns, whereby dominant groups are deemed to belong, and marginalised groups are not (Keenan 2017). Cohabiting carers often have insecure legal relationships to their home. Where the carer is not a legal owner, she is invisible in the eyes of the law, having no formal rights to occupy and only limited rights to remain in the event of relationship breakdown. Her presence within her home depends entirely on her intimate relationship with the legal owner continuing, creating a significant imbalance in power and control within the relationship. If she is unable to show evidence of an intention to share beneficial ownership, there is no formal recognition of her relationship to her home, even if she has a strong emotional connection to it or has lived there for a long time.

Where the home is jointly owned, the carer is still vulnerable to its loss. Even if she acquires half the value of the home, her reduced financial status will impact on her ability to find a suitable alternative home. In fact, a lump sum may be more of a hindrance than a help to her as it will affect her eligibility for state benefits while her caring obligations will reduce her mortgage capacity.35 Relationship breakdown can therefore bring about a precarious living situation, where the carer is forced to rent in the private sector, with its attendant spatial insecurities and hostilities. While owner-occupied housing provides a certain amount of future security, assured shorthold tenancies can be terminated at short notice and are reliant on the tenant continuing to have an earning capacity into old age.

\section{Carer Resilience: Evaluating State Responses}

In this final section, I briefly consider how the state can respond to relational vulnerability. In common with other vulnerability theorists, I employ the term 'resilience', denoting an individual's ability to withstand or overcome harmful effects of vulnerability. Fineman views

35 The capital limit for means-tested benefits is $£ 16,000$. 
resilience as a set of resources, which can be "physical, human, social, ecological or environmental, and existential" (Fineman 2017, 146). Access to these resources is controlled by the state and its institutions and, within the neoliberal state, they are unequally distributed across the population. However, Fineman $(2017,146)$ stresses that, while resilience "provides an individual with the means and ability to recover from harm, setbacks and the misfortunes that affect our lives", it can never fully eliminate inherent human vulnerability.

As Lotz (2016) has argued, vulnerability scholarship largely neglects resilience as a theoretical concept. Although resilience is described as a set of state-distributed resources (Fineman 2010), questions about its normative commitments remain unaddressed under the universal thesis. In the context of cohabiting carer vulnerability, further interrogation of what it means to be resilient is needed. In contrast to universal vulnerability, relational vulnerability is avoidable and capable of at least partial elimination. For cohabiting carers to become relationally resilient, the unequal relational structures in which they are situated must therefore be rebalanced.

To become resilient, cohabiting carers must be given access to social and material resources. Without these, effective caregiving cannot take place. However, to genuinely foster resilience, the state's distribution of resources must also have an identifiable underlying normative commitment to promote positive and empowering relational networks. Here, I draw on Leckey's and Nedelsky's arguments that positive relational contexts are ones characterised by equality and autonomy (Nedelsky 2011; Leckey 2008). It is important to note that both these concepts are being used in a relational sense here. Equality is not mere sameness of treatment, but a commitment towards equal outcomes, and equal status for caregivers and their breadwinner partners. Simultaneously, autonomy is defined as relational, recognising that, contrary to the classical liberal view, interpersonal connections and commitments are not 
necessarily an impediment to autonomy and that, to be autonomous, we must be recognised as such by others (Nedelsky 2011; Mackenzie and Stoljar 2000).

I will now examine two potential modes of state response to cohabiting carers. The first is to achieve resilience through the distribution of privately-owned assets. The second is through state subsidy schemes, where state institutions provide material resources directly to carers. In the below, rather brief, discussion, I do not intend to posit a legal solution to relational vulnerability. Instead, I am evaluating the extent to which these two different responses address the normative goals of autonomy and equality, prompting a more holistic approach towards reform in this area.

\section{Private Property}

The most common way of dealing with the financial implications of relationship breakdown is through discretionary or fixed judicial redistribution of assets owned by the partners. Such schemes exist for married couples and civil partners in England and Wales and also extend to cohabitants in a number of other jurisdictions. The Law Commission has recommended that cohabitants be granted a statutory right to claim financial relief from a former partner, partially modelled on the Scottish regime under the Family Law (Scotland) Act 2006 (Law Commission 2007). While judicial redistribution usually only applies on relationship breakdown, some jurisdictions also operate community of property, whereby all assets of the partners are treated as being jointly owned. Community of property can be immediate, as it is in South Africa, where joint ownership takes effect from the date of the marriage. Alternatively, community can be deferred, coming into effect only when the relationship breaks down and operating only in respect of certain assets, for example the family home (Cooke et al. 2006; Barlow and Lind 1999). 
State responses based around privately owned property (whether through redistribution or community of property) have certain advantages over direct state subsidies. Certain assets, most notably the family home, are of such high economic value that they could never be matched by state payments. Private property-based schemes can also address some of the temporal aspects of relational vulnerability, particularly spatial vulnerability. The potentially ever-lasting nature of homeownership and the level of control over space that ownership brings has significant advantages over other forms of housing and, through awarding property rights, feelings of insecurity over the future can at least be mitigated. A deferred community of property scheme that is based around giving the caregiver rights to the family home also has the potential to recognise the home's unique combination of economic, emotional, and spatial resilience that cannot be replicated through regular monetary payments (Fox 2007; Radin 1982).

Private property regimes can directly address the imbalance that occurs when one partner is able to amass wealth as a result of the other's assumption of caregiving responsibilities. However, this depends on the particular aims that redistribution or community seek to achieve. For instance, the Matrimonial Causes Act gives judges substantial discretion to achieve "fairness",36 whereas the Family Law (Scotland) Act 2006 only aims to correct economic advantage or disadvantage that has arisen in cohabiting relationships. 37

While private property has some attractions, by itself, it is insufficient to fully redress relational vulnerability. Neither redistribution, nor community of property, tackle power imbalances during the relationship. Community of property is arguably more powerful than redistribution in this sense, as it is framed in terms of giving carers an automatic entitlement to assets, rather being framed in terms of the stronger partner having to give assets up. However, neither scheme

${ }_{36}$ See White $v$ White [2001] 1 AC 596

37 Family Law (Scotland) Act 2006, s 28 (3) 
can ensure equal distribution of resources within the private family unit. Another problem is that private property responses are only of use where the family in fact has adequate capital to ensure financial autonomy on relationship breakdown. As house prices rise and wages stagnate, home ownership is becoming increasingly unrealistic for the younger generations. An increasingly volatile political landscape that is marred by financial crises means that, even for those who do own property, its future value is not as secure as it once was. Therefore, whereas private property can offer equality and autonomy for the middle classes, those who are already at the margins of society, and who often experience the burdens of caregiving particularly acutely, are less likely to be assisted by such a scheme.

Private property responses, particularly discretionary redistribution, also place a burden on caregivers to enforce their rights, while the state remains restrained. In this sense, they do not remove the carer from the patterns of financial dependency that characterise economic vulnerability. If a respondent refuses to comply with legal proceedings, the carer may have to resort to depleting family assets to enforce her entitlement, which will impact on her ability to gain resilience. Over the past two decades, successive governments have drastically curtailed the availability of legal aid for family law disputes, 38 meaning that those who cannot afford to pay for legal representation are forced to self-represent in the courts. As Barlow et al. (2017) have argued, the neoliberal state is increasingly restrained; placing responsibility on citizens to resolve their disputes privately and offering only very limited assistance to ensure that justice is done. Any private property response will therefore only be meaningful if it is accompanied by state measures that ensure genuine access to justice through legal aid, something that seems unlikely in the current political climate.

38 The most dramatic cuts took place under the Legal Aid Sentencing and Punishment of Offenders Act 2012, which removed from scope the majority of private family law matters (including actions for a constructive trust or proprietary estoppel), unless an applicant can show evidence of domestic abuse. 


\section{State Subsidy}

An alternative option is that reallocation of private property be abandoned in favour of a more active state intervention in the form of a direct financial subsidy from the state that is paid in respect of care (or other socially reproductive work) that is performed in the home. This would take the form of non-means tested and unconditional cash payments from the state to the individual who works in the home. It is envisaged that such payments would subsidise caregivers who do not engage in paid work at all, as well as assisting those who work parttime, thus reducing the impact of the second shift. Models of this nature have been proposed by feminists as a means of directly rewarding unpaid labour in the home, as seen in Fraser's (1994) "caregiver parity model", and in the Wages for Housework movement during the 1970s and 1980s (Federici 1975; Dalla Costa and James 1973). A version of this model (albeit limited to childcare rather than a broader range of socially reproductive work) is the Nordic 'cash for childcare' initiatives, whereby parents who elect not to make use of state-subsidised childcare are given cash payments instead, which can be retained by the family or spent on purchasing private care services. 39 Cash for care schemes differ substantially from the current state welfare scheme in this country, because it is envisaged that payments would be made as a direct recognition of the value of care and socially reproductive work, and its non-means tested nature would avoid problems of stigma and scrutiny.

In contrast to private property schemes where the state is relatively restrained, caregiver subsidies involve a direct state response to relational vulnerability and, importantly, one that would place a monetary value on socially reproductive labour, working towards ending its status as an emotional and unproductive endeavour. In this sense, state subsidy carries genuine

\footnotetext{
39 The Finnish scheme, Kotohoidontuki, was introduced in 1985 and is available in respect of children aged 13 (www.kela.fi (accessed 23 August 2018)). The Norwegian scheme, Kontantstøtte, was introduced in 1998 and is available for children aged 1-2 (www.nav.no (accessed 23 August 2018)). The Swedish scheme, Vårdnadsbidrag was introduced in 2008 and is available for children aged 1-2 (www.forsakringskassan.se (accessed 23 August 2018)).
} 
transformative potential in seeking to challenge the current privatisation and devaluation of care, which in turn can have broader societal consequences.

As payments would be made throughout the relationship, rather than only on its breakdown, state subsidy has greater potential than private property to enhance caregiver autonomy during the relationship. Having access to resources during a relationship, even limited ones, can enhance decision-making power and raise self-esteem (Pahl 1988). Research has also shown that financial dependency is frequently a significant obstacle to women being able to leave abusive or harmful relational contexts (Goldsack 1999), which could also be addressed through state subsidy.

Notwithstanding the above, it is important not to overstate the impact of state subsidy. The problem is not merely that the current law fails to reward cohabiting caregivers, but also that it contributes to care's gendered nature by imagining caregiving as a predominantly female activity. State subsidy can indeed seek to raise the status of care by linking it to financial reward, but it is maybe overly optimistic to imagine that this alone would persuade men to take up an equal share of the work. There is a risk, as Craig has argued, that state subsidies "would not necessarily give women the freedom not to provide care" (Craig 2008, 48). In fact, there is a danger that socially constructed gender-roles could be even further entrenched, trapping women in the home, and restricting their ability to gain freedom through paid work. This concern has been raised specifically in relation to the Nordic schemes, and it is notable that these initiatives have been championed largely by right-wing governments and are used mainly by women from immigrant or lower socio-economic backgrounds (Nelander 2007; Ellingsæter 2012). Therefore, caution should be exercised in relation to state subsidy. For radical change to happen, the state must tackle the unequal and gendered distribution of caregiving work. State payments alone are unlikely to achieve this without further social reform and a fundamental reconceptualisation of care and other social reproduction. 
There is insufficient space in this article to adequately discuss the ideal legal solution to carers' relational vulnerability. However, as the above discussion demonstrates, it is important that reformers consider a full range of responses, rather than simply opting for the familiarity of private property distribution. Private property, through distribution or community, certainly has attractions in terms of formally recognising relationships between caregivers and their homes. However, it is an unsatisfactory response if it will only assist the small sector of cohabiting carers where there are sufficient assets to enable financial independence postseparation, and if it does little to address the gendered split of caregiving labour. I am in favour of a more holistic response from the state, potentially drawing on elements of both state subsidy and private property, recognising that the work that carers perform is as vital to society's function as paid economic work and is therefore deserving of a wage in the same way as paid work. However, the precise details of such an imagined scheme lie beyond the scope of this article.

\section{Conclusion}

This article has reframed through a relational vulnerability lens the existing feminist concerns over the legal status of cohabiting caregivers. Drawing and expanding upon the existing scholarship around universal vulnerability, I sought to explain relational vulnerability as an additional, or 'more than ordinary' susceptibility to harm arising when the state positions certain sectors of the population within unequal or unbalanced relational networks. Therefore, the disadvantages faced by cohabiting caregivers cannot be explained through private individual choice but must instead be viewed in the broader context of a state that consistently seeks to devalue and marginalise care. Nor can these disadvantages be seen as purely economic, as the embodied and relational nature of humanity means that cohabiting carers are also exposed to harm on an emotional and a spatial level. 
The judicial tendency to commercialise male domesticity while emphasising the altruistic nature of female caregiving is symptomatic of the state's wider perception of care as gendered and privatised, holding little to no value outside the individual family unit. This is particularly problematic in a modern society where economic self-sufficiency is now expected of all citizens and where the state is increasingly restrained. While today's caregiver is more likely to be engaged in economic work (and can thus be distinguished from her late $20^{\text {th }}$ century counterpart), the pressures upon her due to the state's lack of support have arguably intensified and been rendered more complex.

The state has a duty to remedy the unsatisfactory conditions it has created for cohabiting carers. Carers need to be made resilient through the strengthening of their relational networks. Seeking to address the criticism that vulnerability theorists have tended to neglect resilience somewhat, I considered the normative foundations of resilience, suggesting that it should be based around a promotion of relational autonomy and substantive equality. Using this normative framework, I analysed two potential modes of state response; private property and state subsidy. The aim here was not to propose a definitive solution to the existing problems, but to compare the extent to which two opposing forms of state intervention can achieve the dual goals of autonomy and equality. As outlined, it is likely that the state will need to employ elements of both subsidy and private property to adequately respond to relational vulnerability.

Whichever way a state response is framed, it is imperative that there $i$ a response. The current situation is both untenable and unjust. However, it is equally important that reform debates move beyond their current parameters. Cohabiting carers are relationally vulnerable due to the state's failure to value or support them, not due to autonomous choices to compromise earning capacity. Genuine resilience will not be possible without express acknowledgment of the state's role in producing caregiver vulnerability. 
Acknowledgments: I would like to thank Rosie Harding, Tatiana Cutts, Régine Tremblay, and Alan Brown for their comments on previous drafts of this article. I would also like to thank the anonymous reviewers and the Feminist Legal Studies editorial board for their detailed and constructive feedback, which has vastly improved the article.

\section{References}

Adam, Barbara. 1995. Timewatch. Cambridge: Polity Press.

Auchmuty, Rosemary. 2016. The limits of marriage protection: In defence of property law. Onati Socio-Legal Studies 6: 1196-1224.

Barlow, Anne. 2007. Configuration(s) of unpaid caregiving within current legal discourse in and around the family. Northern Ireland Legal Quarterly 58: 251-267.

Barlow, Anne, Carole Burgoyne, Elizabeth Clery et al. 2008. Cohabitation and the law: Myths, money and the media. British Social Attitudes 24: 29-52.

Barlow, Anne, and Craig Lind. 1999. A matter of trust: The allocation of rights in the family home. Legal Studies 19: 468-488.

Barlow, Anne, and Janet Smithson. 2010. Legal assumptions, cohabitants' talk and the rocky road to reform. Child and Family Law Quarterly 22: 328-335.

Barlow, Anne, Rosemary Hunter, Janet Smithson and Jan Ewing. 2017. Mapping paths to family justice: Resolving family disputes in neoliberal times. London: Palgrave Macmillan.

Berkovitch, Nitza. 1997. Motherhood as a national mission: The construction of womanhood in the legal discourse in Israel. Women's Studies International Forum 20: 605-619.

Bottomley, Anne. 1998. Women and trust(s): Portraying the family in the gallery of law. In Land law, themes and perspectives ed. John Dewar and Susan Bright, 206-228. Oxford: Oxford University Press.

Bottomley, Anne, and Simone Wong. 2006. Shared households: A new paradigm for thinking about the reform of domestic property relations. In Feminist perspectives on family law ed. Alison Diduck and Katherine O'Donovan, 39-58. London: Routledge Cavendish.

Brown, Wendy. 1992. Finding the man in the state. Feminist Studies 18: 7-34.

Burgoyne, Carole. 2004. Heart-strings and purse-strings: Money in heterosexual marriage. Feminism \& Psychology 14: 165-172. 
Burgoyne, Carole, Victoria Clarke and Maree Burns. 2011. Money management and views of civil partnership in same-sex couples: Results from a UK survey of non-heterosexuals. The Sociological Review 59: 685706.

Cantillon, Sara. 2013. Measuring differences in living standards within households. Journal of Marriage and Family 75: 598-610.

Chapman, Tony, and Jenny Hockey. 1999. The ideal home as it is imagined and as it is lived. In Ideal homes? Social change and domestic life ed. Tony Chapman and Jenny Hockey, 1-14. Abingdon: Routledge.

Cooke, Elizabeth, Anne Barlow and Therese Callus. 2006. Community of property-A regime for England and Wales?. Nuffield Foundation.

Craig, Lyn. 2008. Valuing by doing: Policy options to promote sharing the care. Journal of the Association for Research on Mothering 10: 45-57.

Crompton, Rosemary and Claire Lyonette. 2008. Who does the housework? The division of labour within the home. British Social Attitudes 24: 53-80.

Crompton, Rosemary and Claire Lyonette. 2015. Sharing the load? Partners' relative earnings and the division of domestic labour. Work, Employment and Society 29: 23-40.

Dalla Costa, Mariarosa and Selma James. 1973. The power of women and the subversion of the community. Bristol: Falling Wall Press.

Davies, Margaret. 2007. Property: Meanings, histories, theories Abingdon: Routledge.

Davies, Margaret.2011. Feminism and the idea of law.feminists@law1.

Dodds, Susan. 2007. Depending on care: Recognition of vulnerability and the social contribution of care provision. Bioethics 21: 500-510.

Douglas, Gillian, Julia Pearce and Hilary Woodward. 2009. Cohabitants, property and the law: A study of injustice. Modern Law Review 72: 24-47.

Easthope, Heather, Edgar Liu, Bruce Judd, et al. 2015. Feeling at home in a multigenerational household: The importance of control. Housing, Theory and Society 32: 151-170.

Elizabeth, Vivienne. 2001. Managing money, managing coupledom: A critical examination of cohabitants' money management practices. The Sociological Review 49: 389-411.

Ellingsæter Anne-Lise. 2012. Cash for childcare. Experiences from Finland, Norway and Sweden. International Policy Analysis, Friedrich Ebert Stiftung. 
Ekerdt, David, and Jennifer Hackney. 2002. Workers' ignorance of retirement benefits. The Gerontologist 42: 543-551.pa

Everingham, Christine. 2002. Engendering time: Gender equity and discourses of workplace flexibility. Time \& Society 11: 335-351.

Federici, Silvia. 1975. Wages against housework. Bristol: Falling Wall Press.

Fineman, Martha. 2004. The autonomy myth: A theory of dependency. New York: The New Press.

Fineman, Martha. 2008. The Vulnerable subject: Anchoring equality in the human condition. Yale Journal of Law \& Feminism 20: 1-24.

Fineman, Martha. 2010. The vulnerable subject and the responsive state. Emory Law Journal 60: 251-276.

Fineman, Martha. 2017. Vulnerability and inevitable inequality. Oslo Law Review 4: 133-149.

Flynn, Leo, and Anna Lawson. 1995. Gender, sexuality and the doctrine of detrimental reliance. Feminist Legal Studies 3: 105-121.

Fox, Lorna. 2007. Conceptualising home: Theories, laws and policies. London: Hart.

Fox-O’Mahony, Lorna. 2014. Property outsiders and the hidden politics of doctrinalism'. Current Legal Problems 62: 409-445.

Fraser, Nancy. 1994. After the family wage: Gender equity and the welfare state. Political Theory 22: 591-618.

Fudge, Judy. 2005. The new dual-earner gender contract: Work-life balance or workingtime flexibility. In Labour law, work and family: Critical and comparative perspectives ed. Joanne Conaghan and Kerry Rittich, 261-288. Oxford: Oxford University Press.

Gardner, Simon. 1993. Rethinking family property. Law Quarterly Review 109: 263-300.

Gardner, Simon, and Katharine Davidson. 2012. The Supreme Court on family homes. Law Quarterly Review 128: $178-183$.

Gardner, Simon, and Emily MacKenzie. 2015. An introduction to land law Oxford: Hart.

Goldsack, Laura. 1999. A haven in a heartless world? Women and domestic violence. In Ideal homes?: Social change and domestic life ed. Tony Chapman and Jenny Hockey, 121-132. Abingdon: Routledge.

Gough, Orla. 2001. The impact of the gender pay gap on post-retirement earnings. Critical Social Policy 21: 311 334.

Grabham, Emily. 2016. Brewing legal times: Things, form, and the enactment of law. Toronto: University of Toronto Press. 
Gurney, Craig. 1997. “... Half of me was satisfied”: Making sense of home through episodic ethnographies. Women's Studies International Forum 20: 373-386.

Hayward, Andrew. 2012. 'Family property'and the process of 'familialisation'of property law. Child and Family Law Quarterly 24: 284-303.

Hochschild, Arlie. 1983. The managed heart: Commercialization of human feeling. Berkley: University of California Press.

Hochschild, Arlie, and Anne Machung. 2012. The second shift: Working families and the revolution at home. London: Penguin.

Hooyman, Nancy, Collette Browne, Ruth Ray, et al. 2002. Feminist gerontology and the life course. Gerontology \& Geriatrics Education 22: 3-26.

Hoskyns, Catherine and Shirin Rai. 2007. Recasting the global political economy: Counting women's unpaid work. New Political Economy 12: 297-317.

Keenan, Sarah. 2017. Smoke, curtains and mirrors: The production of race through time and title registration. Law and Critique 28: 87-108.

Kotiswaran, Prabha. 2015. Valverde's chronotopes of law: Reflections on an agenda for socio-legal studies. Feminist Legal Studies 23: 353-359.

Law Commission. 2007. Cohabitation: The financial consequences of relationship breakdown Law Com. No. 307 London: Law Commission.

Leckey, Robert. 2008. Contextual subjects: family, state and relational theory. Toronto: University of Toronto Press.

Lewis, Jane. 2001. The decline of the male breadwinner model: Implications for work and care. Social Politics 8: 152-169.

Lotz, Mianna. 2016. Vulnerability and resilience: A critical nexus. Theoretical Medicine and Bioethics 37: 45-59.

Mackenzie, Catriona, Wendy Rogers and Susan Dodds. 2014. Vulnerability: New essays in ethics and feminist philosophy. Oxford: Oxford University Press.

Mackenzie, Catriona, and Natalie Stoljar. 2000. Introduction: autonomy refigured. In Relational autonomy: Feminist perspectives on autonomy, agency, and the social self ed. Catriona Mackenzie and Natalie Stoljar, 3-31. Oxford: Oxford University Press.

Meagher, Gabrielle. 2002. Is it wrong to pay for housework? Hypatia 17: 52-66. 
Nedelsky, Jennifer. 2011. Law's relations: A relational theory of self, autonomy, and law. New York: Oxford University Press.

Nelander, Åsa. 2007. Vårdnadsbidrag_En tillbakagång i svensk familjepolitik. Stockholm: Arbetarorelsens Tankesmedja.

O'Donovan, Katherine. 1985. Sexual divisions in law. London: Weidenfeld and Nicolson.

Orel, Nancy, Ruth Ford and Charlene Brock. 2004. Women's financial planning for retirement: The impact of disruptive life events. Journal of Women \& Aging 16: 39-53.

Orel, Nancy, Laura Landry-Meyer and Maria Spence. 2007. Women's caregiving careers and retirement financial insecurity. Adultspan Journal 6: 49-62.

Pahl, Jan. 1983. The allocation of money and the structuring of inequality within marriage. Sociological Review 31: 237-262.

Pahl, Jan. 1988. Earning, sharing, spending: Married couples and their money. In Money matters ed. Robert Walker and Gillian Parker, 195-211. London: Sage.

Pahl, Jan. 1989. Money and marriage. London: Macmillan.

Pateman, Carole. 1988. The sexual contract. Cambridge: Polity Press.

Penning, Margaret, and Zheng Wu. 2015. Caregiver stress and mental health: Impact of caregiving relationship and gender. The Gerontologist 56: 1102-1113.

Pinquart, Martin, and Silvia Sörensen. 2006. Gender differences in caregiver stressors, social resources, and health: An updated meta-analysis. The Journals of Gerontology Series B: Psychological Sciences and Social Sciences 61: 33-45.

Probert, Rebecca. 2001. Trusts and the modern woman: Establishing an interest in the family home. Child and Family Law Quarterly 13: 275-286.

Radin, Margaret. 1982. Property and personhood. Stanford Law Review: 957-1015.

Rai, Shirin, Catherine Hoskyns and Dania Thomas. 2014. Depletion: The cost of social reproduction. International Feminist Journal of Politics 16: 86-105.

Ridgway, Priscilla, Alexa Simpson, Freidnder Wittman et al. 1994. Home making and community building: Notes on empowerment and place. The Journal of Behavioral Health Services and Research 21: 407-418.

Sandhu, Kalwinder. 2016. Universal Credit and impact on black and minority ethnic communities. London: Race Equality Foundation.

Saunders, Peter. 1989. The meaning of 'home' in contemporary English culture. Housing Studies 4: 177-192. 
Sellman, Derek. 2005. Towards an understanding of nursing as a response to human vulnerability. Nursing Philosophy 6: 2-10.

Sloan, Brian. 2015. Keeping up with the Jones case: Establishing constructive trusts in 'sole legal owner' scenarios. Legal Studies 35: 226-251.

Smith, Olivia. 2014. Litigating discrimination on grounds of family status. Feminist Legal Studies 22: 175-201.

Thompson, Janna. 2014. Being in time: Ethics and temporal vulnerability. In Vulnerability: new essays in ethics and feminist philosophy ed. Catriona Mackenzie, Wendy Rogers and Susan Dodds, 162-180. Oxford: Oxford University Press.

Travis, Mitchell. 2018. The vulnerability of heterosexuality: Consent, gender deception and embodiment. Social \& Legal Studies 27: 1-24.

Travis, Mitchell, and Fae Garland. 2018. Legislating intersex equality: Building the resilience of intersex people through law. Legal Studies 38: 587-606.

Tronto, Joan. 1994. Moral boundaries: A political argument for an ethic of care. New York, London: Routledge.

Williams, Allison. 2002. Changing geographies of care: Employing the concept of therapeutic landscapes as a framework in examining home space. Social Science \& Medicine 55: 141-154.

Williams, Fiona. 2010. Migration and care: Themes, concepts and challenges. Social Policy and Society 9: 385396.

Young, Iris Marion. 1995. Mothers, citizenship, and independence: A critique of pure family values. Ethics 105: 535-556.

Zelizer, Viviana. 1997. The social meaning of money. New Jersey: Princeton University Press. 